\title{
Genetics and Molecular Pathophysiology of Thrombotic States
}

\author{
Ludek Slavik
}

Additional information is available at the end of the chapter

http://dx.doi.org/10.5772/56528

\section{Introduction}

Venous thrombosis is a multifactorial disease frequently related to the interaction of genetic and environmental risk factors. Testing for specific mutations in these patients helps to determine the decision on the duration of anticoagulant therapy, risk stratification for primary or secondary prophylaxis. Some of the recently discovered genetic risk factors, such as factor V Leiden and prothrombin G20210A mutations, are quite common in the population. When compared to functional assays, molecular assays provide clear results without different cutoff values. Accordingly, laboratory investigation of thrombophilic disorders has expanded due to incorporation of modern molecular assays. Criteria used to select specific DNA methodologies reflect the issues of cost, automation, speed, reliability, and simplicity for specific diagnostics. A variety of currently used molecular methods fulfill many, but not all of these criteria. The new methods of real-time PCR and DNA microarrays offer the potential for widespread application and utility in the future. Problems arise with interpretation in many new polymorphisms without significant clinical relevance.

Let's look at the history of molecular diagnosis of thrombophilia. Since the very beginning of the diagnosis of thrombophilic disorders, which arose from the study of families with a high frequency of thrombophilic complications, it was apparent that in a number of cases, the disorder was due to dominantly inherited conditions. Already the discovery of the first families presenting a defect in antithrombin (AT) led to the description of the genetic causes of this defect. As such, over 150 causes of AT mutation were described.

Molecular genetic methods were implemented into the screening examinations for thrombophilic disorders in the 1990's along with the first discoveries of coagulation inhibitors (AT, protein C and protein S). The discovery of the molecular cause of activated protein C (APC) resistance by Bertina in 1994 greatly expanded their utilization. 


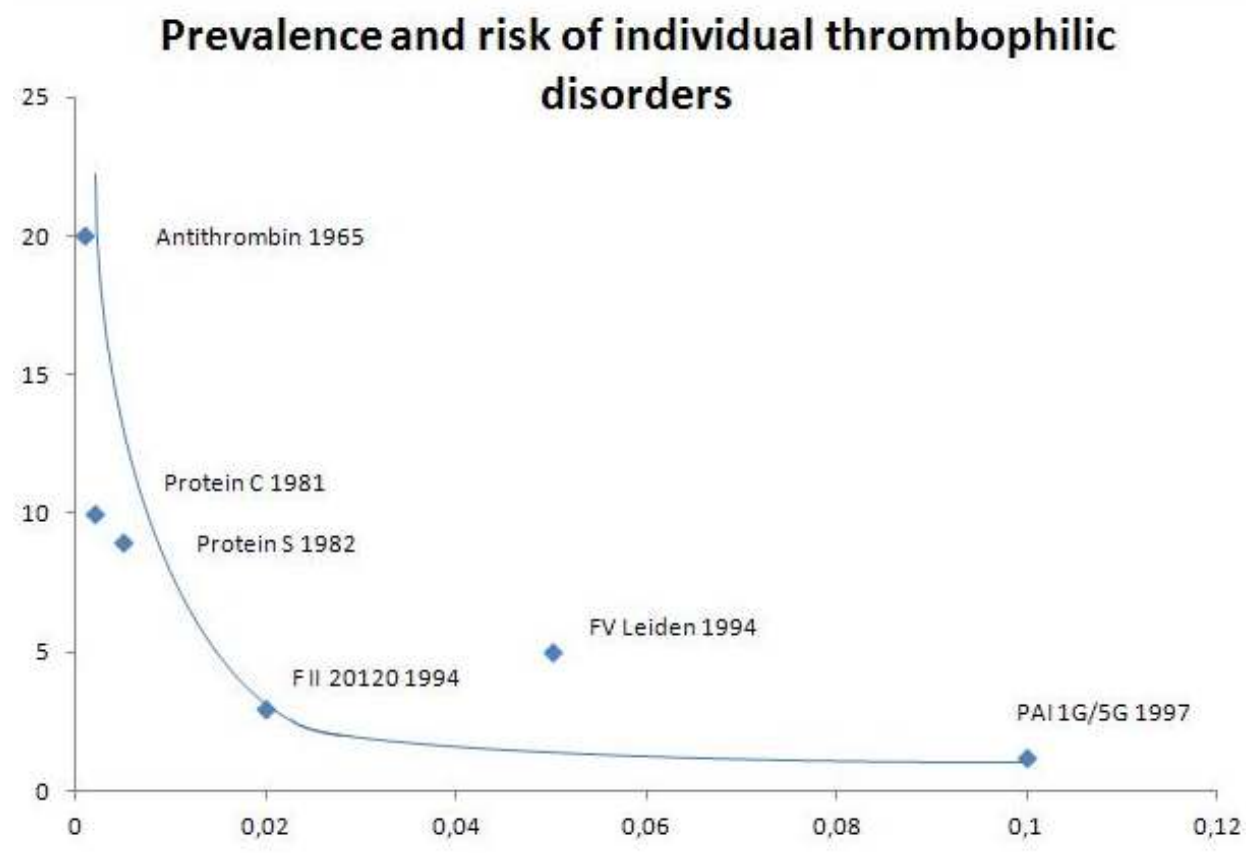

Figure 1. Prevalence and risk of individual thrombophilic markers with a time line representing their discovery[1] Despite the expansion of these methods, the following years brought forth discoveries of defects on a molecular basis, which posed decreasing risks of thrombosis, as can be seen in Fig 1. However, until the end of the last century, it has been assumed that further investigations of genetic causes of thrombophilia are needed to clarify the risk of this disorder in a more detailed manner. Currently, it is apparent that there is a deflection from this idea and attention is focused rather on the elucidation of the complex pathophysiology of coagulation at the molecular level.

Successive determination of relative risk of individual factors and their prevalence in the population led to the gradual definition of the panel of genetic thrombophilia. Currently, they can be divided into two groups i.e.1/ a well-defined genetic thrombophilic risk factors and 2/ potential risks factors of thrombophilia.Well-defined VTE risk factors include resistance to activated protein C (APCR) often due to factor V Leiden (FVL), prothrombin G20210A gene mutation (FII G20210A), high factor VIII (FVIII) activity or homocysteine level, and natural anticoagulant deficiencies: antithrombin (AT), protein C (PC), and protein S (PS). Patients with laboratory-confirmed thrombophilia are at greater risk for VTE, but most will never have such an event[2]. VTE risk increases synergistically as other risk conditions are acquired (eg, pregnancy, trauma, immobilization). More than $60 \%$ of patients with idiopathic (spontaneous or unprovoked) VTE have inherited thrombophilia[3].

An individual's risk for VTE would be determined by the combination of baseline propensity for thrombosis and the magnitude of the acute insult. In the face of genetically increased baseline hypercoagulability (major genetic thrombophilic state) even a relatively weak insult (e.g., blood stasis during a flight) can be sufficient to precipitate DVT. Likewise, in an indi- 
vidual with a relatively low level of baseline genetic hypercoagulability (potential genetic thrombophilic state) a relatively strong thrombogenic event (e.g., pregnancy) may be required to provoke an episode of VTE[4]. Thus, the precipitating event in such individuals is often clinically overt. In most cases, such thrombophilic individuals never suffer VTE throughout their lifetimes, and when they do have an episode, it is unlikely to recur. In contrast, an individual with a high level of baseline genetic hypercoagulability is at such high risk that relatively minor acquired triggers can initiate a thrombotic episode. These triggers are therefore subclinical, giving the appearance that the patient has "idiopathic", "spontaneous", or "unprovoked" VTE.

\begin{tabular}{lcc}
\hline Thrombophilia & Prevalence* (\%) & Relative risk \\
\hline Antitrombin deficiency & 0.02 & 10 \\
\hline Protein C deficiency & $0.2-0.4$ & 10 \\
\hline Protein S deficiency & $<1$ & 10 \\
\hline FV Leiden (G1691A) homozygosity & 0.02 & 50 \\
\hline FV Leiden (G1691A).heterozygosity & $5-7$ & $5-7$ \\
\hline F II (G20210A) & $2-7$ & $2-3$ \\
\hline Fibrinogen gamma 10034T & 6 & 2 \\
\hline * prevalence in Caucasian population & & \\
\hline
\end{tabular}

Table 1. Prevalence and relative risk of venous thromboembolism associated with well defined major genetic risk factors[5]

\section{Major genetic thrombophilic states}

Major genetic thrombophilic states include defects with clinically confirmed risk for VTE and an understanding of the pathophysiological action of these defects.

\subsection{Antithrombin}

Egeberg first described familial antithrombin III deficiency, now termed antithrombin deficiency, in 1965[6]-[8]. This first work already pointed out that antithrombin deficiency is a significantly more serious risk factor for developing thrombosis than protein $\mathrm{C}$ and $\mathrm{S}$ deficiency, and that the majority of patients show clinical manifestation before the age of 25[7], [9]. This does not pertain to changes of the heparin binding site, which occurs frequently, and does not present a risk in the heterozygous form[9].

Based on extensive studies, the thrombotic risk for patients with AT deficiency was determined to be increased five-fold, based on the $1.1 \%$ prevalcence of this deficiency in patients with venous thrombosis compared to $0.2 \%$ prevalence in the control group[10]. Other studies 
determined the prevalence of AT deficiency to be between $1-0.5 \%$ [6]. There are two primary types of antithrombin deficiency: type I and type II. Type I antithrombin deficiency is characterized by an inadequate amount of normal antithrombin present. In this case, there is simply not enough antithrombin present to inactivate the coagulation factors. In type II antithrombin deficiency, the amount of antithrombin present is normal, but it does not function properly and is thus unable to carry out its normal functions. In many cases, the antithrombin in type I deficiencies has a problem binding to heparin, although there have been multiple other changes to the antithrombin molecule described.

Antithrombin deficiency may be assessed by chromogenic or clotting laboratory methods. The chromogenic assay is the most simple and usually preferred. Overall, there are fewer confounders with antithrombin activity assays than with protein $\mathrm{C}$ or protein $\mathrm{S}$ activity assays; partly because chromogenic antithrombin activity assays are performed rather than clotbased[11]. For antithrombin activity, chromogenic (IIa- or Xa-) based assays which are not affected by heparin are available. Thrombin (IIa)-based assays, in theory, can be falsely elevated by elevated heparin cofactor II because heparin cofactor II is a natural inhibitor of thrombin. Factor Xa-based assays might be less sensitive to type II deficiencies than the IIabased assays[12]. Direct thrombin inhibitors falsely increase results in IIa-based assays but not with Xa-based assays, because they inhibit factor IIa but not factor Xa[13].

A false-positive result for a type II deficiency may occur in the presence of a heparin-binding site (HBS) mutation. Extending the incubation time of the activity assay to $300 \mathrm{sec}$ may help normalize results, since the extra time allows the assay to overcome this limitation and normalize results, whereas other (clinically important) mutations remain abnormal[14]. In general, HBS mutations are thought to be not significant except in homozygotes[14].

Another caveat with antithrombin testing involves different type II mutation called antithrombin Cambridge II A384S[15],[16]. Heterozygotes and homozygotes with this mutation were found to have normal activity in an anti-Xa assay (and appropriately low activity with an anti-IIa-based assay). Heterozygosity was found in $0.1-0.2 \%$ of the general population and $0.4-1.7 \%$ of patients with venous thrombosis. Heterozygosity was associated with a ninefold increased risk for venous thrombosis. The main disadvantage of screening for deficiency using an antithrombin antigen assays is that type II (qualitative) deficiencies will not be detected.

\subsection{Protein C}

The first studies demonstrating increased risk of thrombosis in patients with heterozygous protein C deficiency were presented in 1981[17],[18]. No difference between patients with various types of deficiency (I or II) and basic mutation were noted. These studies showed that a large majority of patients already has clinical manifestations of the disease at a young age[19]. In addition, it is interesting to note that in some patients, APC resistance was also present as an additional factor increasing the risk of thrombosis[20].

The prevalence of protein $C$ deficiency in patients with venous thromboembolism has been determined to exist approximately 3\%[21]-[23] compared to $0.2 \%$ prevalence in the healthy population[18]. When compared with the control group, the relative thrombotic risk for 
protein C deficiency is apprixomately 6.5 fold[24]. Despite the relatively low population prevalence, the high risk of thrombogenicity results in a $1-2 \%$ contribution of protein $C$ deficiency on all thrombophilic conditions.

Protein C deficiency can be detected by chromogenic or clotting methods. Both assays may have pitfalls in testing. Clot-based assays are aPTT- or Russell viper venom (RVV) based, either of which can give falsely high results in the presence of direct thrombin inhibitors. With aPTTbased assays, lupus anticoagulants can cause falsely high results and elevated factor VIII or factor V Leiden can cause falsely low results. Heterozygous factor V Leiden did not appear to affect an RVV-based assay, but artificially low protein $C$ results in homozygous factor V Leiden patients could not be excluded due in part to the small number of such patients[25]. Lupus anticoagulants did not falsely increase protein C levels using an RVV-based assay[25], but according to the manufacturer, the possibility of lupus anticoagulant interference cannot be excluded.

There are two primary types of antithrombin deficiency: type I and type II. Type I antithrombin deficiency is characterized by an inadequate amount of normal antithrombin present. In this case, there is simply not enough antithrombin present to inactivate the coagulation factors. In type II antithrombin deficiency, the amount of antithrombin present is normal, but it does not function properly and is thus unable to carry out its normal functions. In many cases, the antithrombin in type I deficiencies has a problem binding to heparin, although there have been multiple other changes to the antithrombin molecule described. None of these conditions affect chromogenic assays, but there is a rare type II variant that might not be detected by chromogenic assays but is detected by clot-based assays. More recently, another rare variant, Asn2Ile, has been identified that is missed by chromogenic assays, and it is also missed by some clotbased assays[26]. Testing protein $C$ while on warfarin therapy is not recommended because warfarin decreases protein C (and protein S) levels. However, if testing is inadvertently sent while on warfarin, the result with a chromogenic assay is typically higher than with clot-based assays.

\subsection{Protein $S$}

Protein $S$ is an important anticoagulant protein, which acts as a non-enzymatic co-factor of activated protein C (APC) during inactivation of factor Va and VIIIa. Laboratory screening of protein $S$ deficiency is complicated by the fact that protein $S$ circulates in bloodstream in two forms, i.e. bound and free[27]. Forty percent of total protein $S$ is represented by free protein $S$, which acts as the APC co-factor.

Protein S deficiency may be divided into three basic forms. Type I is characterized by a decrease in total protein S most often due to decreased synthesis, type II is characterized by decreased protein S activity and type III by a decreased level of free protein $S$ and normal activity of total protein S.

Most deficits are type I or a combination of types I and III. At present very few cases of type II protein $S$ deficiency have been described. The prevalence of protein $S$ deficiency represents $1-2 \%$ of patients with deep venous thrombosis and $6 \%$ of families with thrombophilia. From 
a genetic viewpoint, 70 different mutations in the gene for protein $S$ have been described to date.

The detection of protein S deficiency is complicated, because protein S circulated in the blood stream in two forms, i.e. bound protein $\mathrm{S}$ associated with $\mathrm{C} 4 \mathrm{~b}$ binding protein $(60 \%)$ and free protein S (40\%). The thrombotic risk potential constitutes only free protein S. Protein S activity may be determined using clot-based (aPTT, PT, Xa or RVV) assays. A number of factors may interfere with clot based assays. Lupus anticoagulants or direct thrombin inhibitors[28] can cause falsely elevated results. Factor V Leiden can cause falsely low results with PT-, Xa-, RVV-, and some aPTT-based assays[29]-[31]. With aPTT-based assays, elevated factor VIII can cause falsely low results because factor VIII shortens the aPTT in the assay.

Protein S free or total antigen assays do not suffer from similar limitations. Acute phase reactions (e.g., illness, inflammation) can falsely decrease protein $S$ in vivo, and it is a common cause of low protein $S$ activity or decreased free antigen results (but not total protein $S$ antigen). This effect is attributed to C4b-binding protein, which becomes elevated during acute phase reactions. $\mathrm{C} 4 \mathrm{~b}$-binding protein binds to protein $\mathrm{S}$, thus reducing the amount of free protein $\mathrm{S}$. When protein $S$ is bound to $C 4 b$-binding protein, it is essentially inactive. The main disadvantage of free or total protein $S$ antigen assays is that type II deficiencies will not be detected[32], but the majority of hereditary protein S deficiencies are type I (quantitative).

\section{Factor V Leiden and APC resistance}

The detection of Factor V Leiden (FVL) is usually performed as genetic confirmation of activated protein $\mathrm{C}$ (APC) resistance positivity. The classical assay for activated protein $\mathrm{C}$ resistance detects a ratio between a baseline activated partial thromboplastin time (aPTT) and the aPTT with APC. A variety of conditions can cause "falsely elevated" or "falsely decreased" ratios and interfere with this test, rendering it somewhat insensitive and nonspecific for diagnosing FVL, However, a positive result of APC resistance, due to acquired factors, may pose the same risk as the presence of the FVL mutation [33].

Elevated factor VIII (FVIII), the presence of a lupus anticoagulant, and certain drugs including oral contraceptives, estrogen, vitamin $\mathrm{K}$ antagonists, heparin, or direct thrombin inhibitors may interfere with the traditional aPTT-based APC assay. Improved assays are available, including the second-generation assay for activated protein $\mathrm{C}$ resistance, with sensitivity and specificity approaching $100 \%$ for the diagnosis of factor V Leiden[34]. The modification involves diluting the patient plasma into factor $V$-deficient plasma, thus minimizing the effect of factor V deficiencies and factor FVIII elevations that alter the baseline aPTT. Despite these changes, lupus anticoagulants may cause falsely low ratio results and direct thrombin inhibitors can cause falsely normal ratio results[35],[66].

Newer test options include Russell viper venom (RVV)-based assays, which uses the factor $\mathrm{X}$ activator from RVV. The reagent contains phospholipid designed to reduce lupus anticoagulant interference. 
A factor Xa-based clotting assay is a third type of new assay for APC resistance. The method includes dilution into a proprietary reagent containing purified factors II, fibrinogen, protein $\mathrm{S}$, and activated protein $\mathrm{C}$. The inclusion of these factors presumably eliminates interference due to deficiencies or increased levels of these proteins.

While APC resistence positivity caused by presence of lupus anticoagulants is often considered to be "falsely elevated", several studies report that this parameter has some clinical significance.

While APC resistance positivity caused by lupus anticoagulants is often thought of as an "falsely elevated", some studies report that it have clinical significance.

Factor V Leiden can be detected by several DNA assays. In recent years, different molecular approaches, including restriction fragment length polymorphism (RFLP) and real-time PCR, have been developed to genotype single nucleotide polymorphisms (SNPs). Compared with more traditional methods such as RFLP, real-time PCR is a fast, simple, and accurate procedure for SNP genotyping of medium to large collections of samples. Real-time PCR analysis can be performed using various strategies[5]. In the hydrolysis assay, the probe and fluorescent chromogen is released by hydrolysis during PCR amplification and the free probe quantity is proportional to the fluorescence[37]. Fluorescence resonance energy transfer (FRET) is a method that distinguishes alleles by melting the products and monitoring the loss of fluorescence using an allele-specific oligonucleotide probe which hybridizes to specific sequences[38]-[40].

High-resolution melting analysis with LCGreen ${ }^{\mathrm{TM}} \mathrm{I}$ is a newly designed analysis that detects heteroduplexes during homogeneous melting curve analysis with a new fluorescent DNA dye[41]. Genotyping of single-nucleotide polymorphisms (SNPs)1 by high-resolution melting analysis in products as large as $544 \mathrm{bp}$ has been reported. This allows closedtube, homogeneous allele-specific PCR genotyping [45],[46], on real-time PCR instruments without fluorescently labeled probes[42]-[44]. Heterozygotes are identified by a change in melting curve shape, and different homozygotes are distinguished by a change in melting temperature $(\mathrm{Tm})$. However, it is still not clear whether all SNPs can be genotyped by this method[45]-[47].

Among the Caucasian population, factor V Leiden (factor V 1691G-A) is the most common genetic defect causing thrombosis[48]-[54]with a frequency between 2 and $15 \%$ [49].. Factor V mutation was first described by Bertina et al in 1994 at the University of Leiden[55], based on the discovery of resistance to activated protein C (APC), which was first described in 1993[56]. The heterozygous form of factor V Leiden increases the risk of thrombosis $3-8 x$ [49],[57],[58], while the homozygous form presents a risk which may be up to 80 times greater[59].

Factor V Leiden is present in up to $20 \%$ of patients with venous thrombosis[50],[57] and in over half of probands in selected families with thrombophilia making it the most common genetic abnormality in patients with thrombosis. 


\section{Pathophysiology of action FV Leiden mutation}

FV plays a key role in both the procoagulation and anticoagulation cascade processes. In the activated form, it acts as a co-factor for FXa in the prothrombinase complex and as such catalyses the conversion of prothrombin to thrombin. In the inactive form FV acts as an APC co-factor in the regulatory activity of FVIIIa. In inherited and acquired defects, this double role allows FV to influence the manifestation of these disorders into hemorrhagic or thrombotic forms [60],[61]. To determine this manifestation, it is necessary to recognize precisely the procoagulation and anticoagulation forms of FV[63].

A
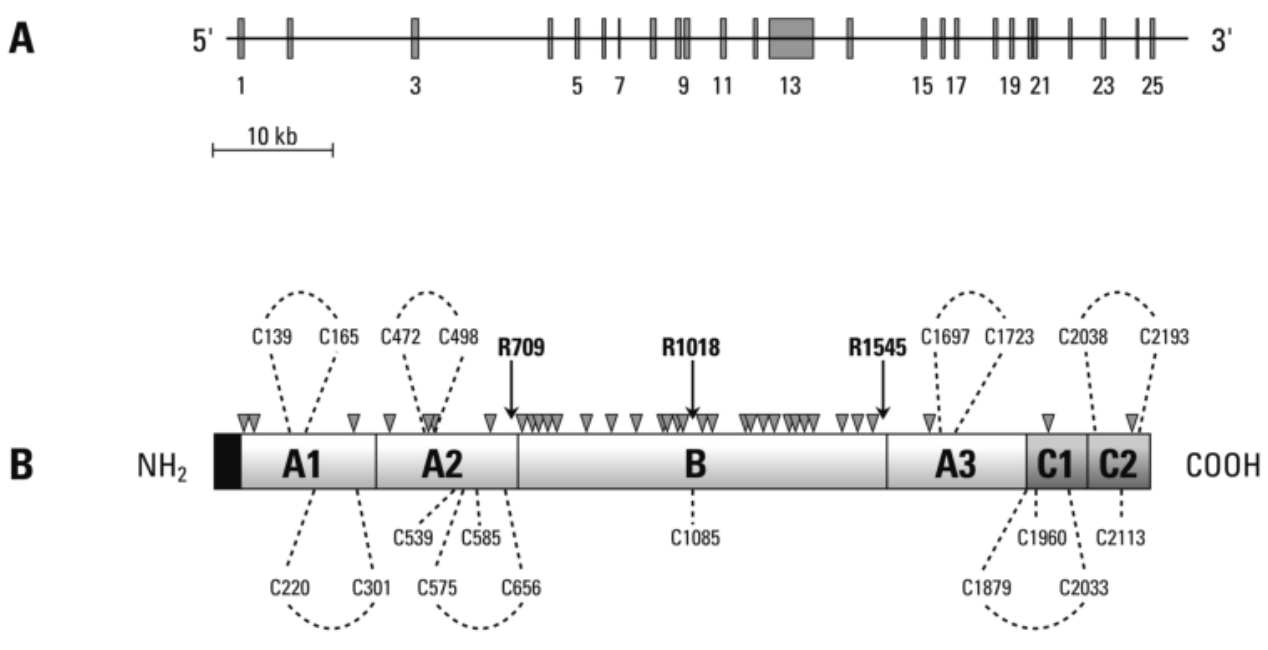

Figure 2. Schematic representation of the structure of FV

Unlike FV, FVa increases the FXa activated conversion of prothrombin in the prothrombinase complex. It may be expected that the cleaved B-domain allosterically inhibits the binding of FV in the active site of FXa [63].

The mechanism by which FVa acts on FXa is not completely understood. Based on the latest works, it may be assumed that FVa increases the binding affinity of FXa to phospholipids by about 100x. In addition, it was determined that FVa in the prothrombinase complex does not change the binding site of FXa, but instead increases the affinity of the prothrombinase complex to prothrombin and ensures an increase in binding sites.

The co-factor activity of FVa is balanced by APC, which proteolytically cleaves FVa at the Arg306, Arg506 and Arg679 sites of the heavy chain. The weakest inactivation is seen during cleavage at the Arg679 site. Latest discoveries suggest two pathophysiological models of FVa cleavage. The first model assumes preferential cleavage at the Arg506 site followed by cleavage at the Arg306 site. Alternatively, FVa may be inactivated directly by cleavage at the Arg306 
site. Cleavage at the Arg506 site also decreases the affinity of FVa to FXa, while cleavage at the Arg306 site causes complete inactivation of FVa [64].

\section{Anticoagulation function of FVa}

Aside from its procoagulation function, FVa also possesses an anticoagulation function, which is expressed as APC activation. In this case it is a cofactor in the proteolytic cleavage of FVIIIa[65]. Recent experimental works supports this model where the addition of purified FV renewed the function of APC in both healthy patients and in families with the Leiden mutation. The experiments utilized measured generation of thrombin.

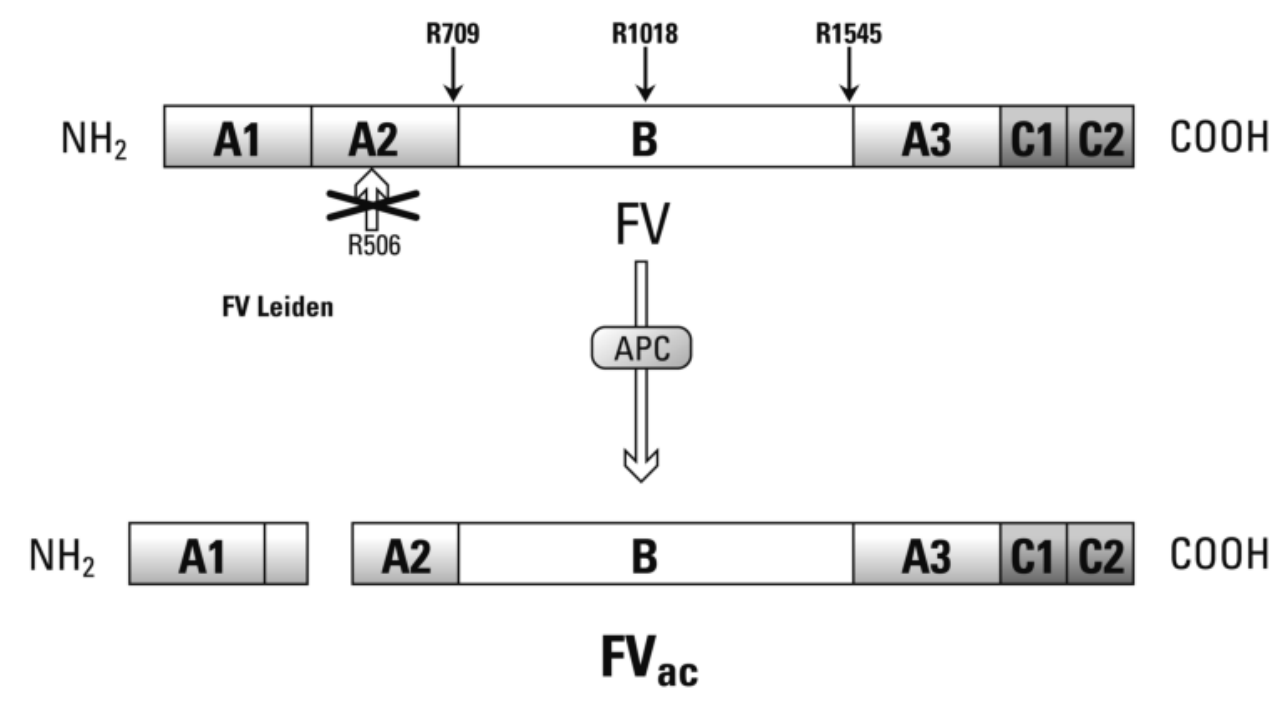

Figure 3. Anticoagulation structure of FV[59]

Thus if the anticoagulation function of FV is required, cleavage must occur in position Arg506. Unlike APC mediated cleavage in sites Arg306 and Arg679, which does not exhibit anticoagulation activity.

\section{FV and thrombophilia}

Such described pathways of FV activation point to the balance of pro- and anticoagulation activity of factor $V$ and its significance in maintaining haemostatic equilibrium. The pathways of FV activation describe the mututal balance of both pro- and anticoagulation activity of factor $\mathrm{V}$ and its significance in maintaining haemostatic equilibrium. 
APC resistance is an in vitro described phenomenon, which is characterized by a slight anticoagulation response to APC in plasma. Such decreased sensitivity to APC leads to inadequate regulation of thrombin production. As such, APC resistance is associated with an increased risk of developing thrombosis. APC resistance is associated with FV Leiden mutation in up to $90 \%$ of cases.

FV Leiden mutation significantly influences the pro- and anticoagulation balance of FVa. The Leiden mutation, which leads to the disappearance of the Arg506 cleavage site, causes an insufficient decrease of the procoagulation activity of FVa, which explains the presence of procoagulation states in carriers of the Leiden mutation.

\section{FV Leiden}
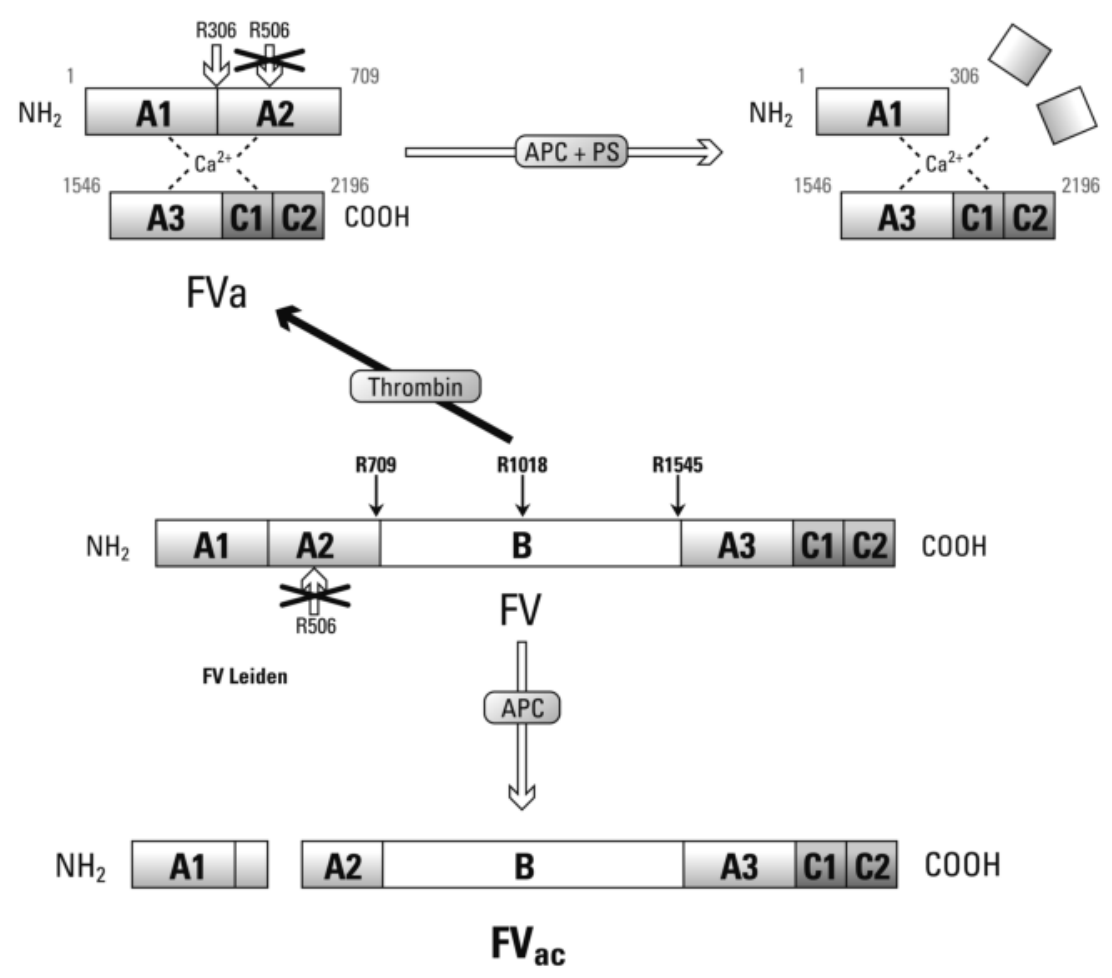

Figure 4. A schematic illustration of the activation of FV to procoagulation and anticoagulation forms

The discovery of a second pathway of action of FVa, where via APC it acts as a co-factor during proteolytic cleavage of FVIIIa aids us in establishing the effect of the Leiden mutation. Since FV with the Leiden mutation does not contain a cleavage site in the position Arg506, the anticoagulation form FVac cannot be produced and therefore there is only weak co-factor activity of APC during FVIII proteolysis. 


\section{Prothrombin 20210A}

Mutations in the $3^{\prime}$ - untranslated region of the prothrombin gene in the position $20210 \mathrm{G}-\mathrm{A}$ are associated with an increased level of prothrombin and as such present an increased risk of developing thrombosis[66]. This mutation was described with a high prevalence (up to 18\%) in families with thrombosis and in $6.2 \%$ of patients with first thrombosis[66].

F II 20210G-A mutation in the gene for prothrombin was found through linkage analysis in families with a history of venous thrombosis and no other congenital or acquired thrombophilic risk factors[67]. The mutation is located in the 3 'gene region, which already does not overwrite to the protein. The mutation is located in the 3 'gene region, which already does not overwrite to the protein. Therefore, it appears difficult to develop a specific functional coagulation tests based FII activity determination. However, in large clinical studies found significantly elevated levels of prothrombin mutations in patients with FII 20210 GThere is no evidence that the homozygous mutation carriers have a higher level of prothrombin than heterozygous. The pathophysiologic influence of the mutation is not yet fully explained. The original view was that the mutation alters the conformation of the pre-mRNA 3'UTR, which has an increased affinity for the production of polyA end. This causes an increased concentration of mRNA with an increase in protein synthesis, so the greater the level of prothrombin in plasma[68]. Later work demonstrated that the mutation does not affect the mRNA level, but instead 3' cleavage/ polyadenylation, which affects abnormal properties of mRNAs[69]. Finally, recent work showing abnormal properties mRNA 20210A mutation in the 3'UTR, which cause the emergence of polyA preferentially in the presence of this mutation in the mRNA[70].

The prevalence of this mutation in the normal population is $1.7 \%$ in northern Europe and $3 \%$ in southern Europe[71],[72]. This mutation is very rare among people of African and Asian origin. It was found that originated as a founder effect until after the separation of Caucasian populations [73]-[76].

Apart from this, the mutation may represent an additional risk factor for spontaneous abortions especially during the first trimester[77]. The risk of venous thrombosis is significantly increased in women with prothrombin mutation during pregnancy and after childbirth,and the frequency of thrombosis further increases in the presence of an additional risk factor, which among others - can be factor V Leiden[78]. Prothrombin mutation may also affect the risk of arterial thrombosis, but this has not been clearly demonstrated yet. In a large group of 3028 patients, a statistically significant relationship between the mentioned mutations and ischemic stroke (odds ratio 1.44) [79] was demonstrated. Ingeneral the risk of spontaneous recurrent thromboembolic events is the same in patients with mutations without such mutations[80].

\section{Potential genetic thrombophilic states}

\subsection{Plasminogen activator inhibitor-1 mutation}

The plasminogen activator inhibitor-1 (PAI-1) mutation is a single base insertion or deletion at position $-675(4 \mathrm{G} / 5 \mathrm{G})$ in the promoter region of the PAI-1 gene, which is associated with 


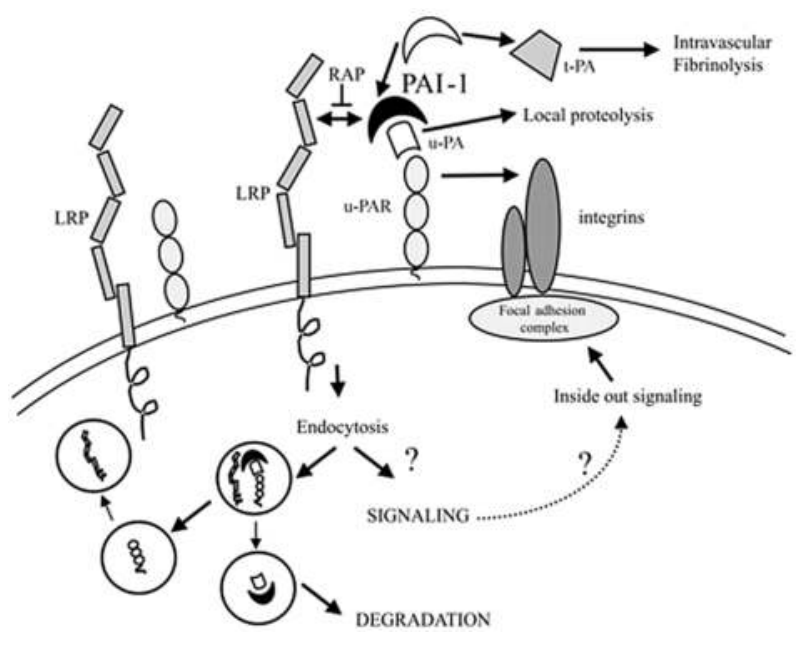

Figure 5. Schematic action PAI-1 in regulation mechanism of fibrinolytic system

higher levels of PAI-1 transcripts and also higher plasma activity of PAI-1[81]. In the PAI-1 $6754 \mathrm{G} / 5 \mathrm{G}$ mutation, the $4 \mathrm{G}$ site binds an enhancer element only, whereas the $5 \mathrm{G}$ allele binds both enhancer and suppressor elements. As a result individuals with $4 \mathrm{G} / 5 \mathrm{G}$ or $4 \mathrm{G} / 4 \mathrm{G}$ genotypes have an increased level of transcription and consequently a higher PAI-1 protein level than individuals with $5 \mathrm{G} / 5 \mathrm{G}$ polymorphism. Because PAI- 1 is a rapid inhibitor of tissue plasminogen activator (t-PA), the $4 \mathrm{G} / 5 \mathrm{G}$ variant of mutation can increase the activity of PAI-1 and decrease the conversion of plasminogen to plasmin, which causes decreased fibrin degeneration and increased clot stabilization.

Under physiological conditions, PAI-1 is released into the circulation and the extracellular space by only a few cells: liver cells, smooth muscle cells (SMC), adipocytes, and platelets are the major sources of PAI-1. This results in plasma levels of only 5-20 ng/ml of active PAI-1, sufficient to control fibrinolysis and extracellular proteolysis.

Under pathological conditions, however, several other tissues secrete quite large amounts of PAI-1: tumor cells, endothelial cells in response to inflammatory cytokines, and other inflammation-activated cells. High PAI-1 plasma levels are consistently found in patients with severe sepsis but also with other acute or chronic inflammatory diseases such as atherosclerosis. PAI-1 is upregulated by inflammatory cytokines and may therefore be regarded as a marker for an ongoing inflammatory process. It is of major importance, however, that no classic inflammatory response element was found in the PAI-1 promoter region, and it is still unclear how PAI-1 expression is upregulated during inflammation[82].

\subsection{Fibrinogen}

Fibrinogen is a 340-kDa glycoprotein produced in the liver with a plasma concentration of 180 - $450 \mathrm{mg} / \mathrm{dl}$. It consists of two monomers linked by a disulfide bond. Each monomer consists 
of three polypeptide chains encoded by three distinct genes: $\mathrm{Aa}, \mathrm{Bb}$ and $\gamma$. It binds to the platelet through the glycoprotein $\mathrm{IIb} / \mathrm{III}$ a receptor and, therefore, is highly involved in the thrombotic processes. It also has a direct effect on the vascular wall and blood viscosity. An association between increased circulating levels of fibrinogen and the development of arterial thrombosis has been demonstrated[83],[84]. The mechanisms that explain the association between increased fibrinogen and AMI include increased fibrin formation, increased blood viscosity, platelet hyperaggregability and an increased proliferation of vascular endothelial and smooth muscle cells[85]. In addition, fibrinogen is an acute phase reactant and possibly an indicator of chronic inflammation associated with atherosclerosis.

There are several polymorphisms identified in the genes that code the three polypeptide chains and are associated with increased concentration of circulating fibrinogen ( $>500 \mathrm{mg} / \mathrm{dl})$. From the functional point of view, the most relevant are those in the $\beta$ chain: Arg448Lis, $-148 \mathrm{C} / \mathrm{T}$, $-455 \mathrm{G} / \mathrm{A}$ and $854 \mathrm{G} / \mathrm{A}$, with the last two having the most pathophysiological interest due to their association with the development of vascular disease. The genotype $-455 \mathrm{~A}$ is present in $10-20 \%$ of the general population and is correlated with an increase of $10 \%$ high concentration of fibrinogen, prevalence of other mutations not specifically described in current literature. Some studies[86] showed an association between the -455 polymorphism and an increased risk for arterial thrombosis.

\section{Coagulation factor VII (FVII)}

Factor VII is a single polypeptide chain, 406-amino acid glycoprotein with a weight of $\sim 50,000$ $\mathrm{Da}$. It is vitamin $\mathrm{K}$ dependent protein, synthesized in the liver and has a plasma concentration of $500 \mathrm{ng} / \mathrm{mL}$. FVII is transformed into its activated form (FVIIa) by binding with tissue factor (TF). The TF:FVIIa complex converts Factor IX and Factor $X$ to their active forms, FIXa and FXa. Recent studies have described an association between an increased plasma concentration of FVII and development of arterial thrombosis[87]

In contrast, polymorphism $\operatorname{Arg}(\mathrm{R}) 353 \mathrm{Gln}(\mathrm{Q})$ in the FVII gene is associated with a $20-25 \%$ decreased plasma concentration of FVII.[88]

In addition, several studies[89],[90] have demonstrated that plasma concentration of FVII is lower in subjects homozygous for the 353Gln allele compared with those homozygous for the 353Arg allele.

In contrast, other studies have been unable to corroborate the association of the polymorphism R/Q353 with AMI or increase in plasma concentration of FVII in subjects with Arg/Arg genotype[91].

\section{Polymorphisms in platelets}

Platelets play an important role in the development of acute coronary syndromes. Platelets possess glycoprotein receptors on the surface membrane which participate in platelet activa- 
tion, degranulation and aggregation. These receptors belong to the family of integrins (aIIb B3) and are highly polymorphic, which often produces an antigenic alteration of the glycoprotein. The most frequent polymorphisms present in these glycoproteins are receptors for von Willebrand factor (vWF) (GPIb-IX, GIIb-III), a in the protein receptor for collagen (GPIaIIa), and in the receptor for fibrinogen (GPIIb-IIIa).

The most abundant glycoprotein on the platelet membrane is the GPIIb-IIIa complex. Inactivated platelets bind through GIIb-IIIa complex to vWF and to fibrinogen. This polymorphism consists of a thymine substitution for cytosine in the 1565 position in exon 2 of the GPIII gene[92]. Approximately 25\% of the population of northern Europe is a carrier of at least one allele PLA2 (PLA1/A2). Several studies described an association between this polymorphism and AMI in patients <60 years[93], ACS[94] and atherothrombosis[95]. Many studies have attempted to establish an association between the presence of allele PLA2 and coronary artery disease, but results are still contradictory.

\section{Hyperhomocysteinemia}

Increased levels of homocysteine are associated with an increased risk of thrombosis[96]-[98]. Two studies performed on an undivided group of patients showed that a level above 18.5 $\mu \mathrm{mol} / 1$ in $5 \%$ (10\% respectively) of tested subjects led to a two-fold increase in the risk of thrombotic episodes[99]-[101]. This means that hyperhomocysteinemia represents $5-10 \%$ of all thrombotic episodes.

Hyperhomocysteinemia may develop due to genetic or acquired dispositions[99]. Acquired dispositions primarily include low vitamin intake or resorption (B6, B12, folic acid), which leads to an increase in homocysteine level[101],[102]. Genetic factors include the very rare cystathione $\beta$-synthase deficit, whose homozygous form represents classical hyperhomocysteinemia with very high levels[103], and on the other hand the very common variant of the methyltetrahydrofolate reductase (MTHFR) gene, which leads to the thermolabile enzyme variant with a slightly increased homocysteine level[104]-[106]. Currently, direct association between the MTHFR 677TT variant, increased homocysteine level and risk of developing thrombosis is not distinctly established[107].

\section{Conclusion}

The elucidation of the precise pathogenesis of action leads to the conclusion that to explain the clinical expression of thrombophilic conditions, it is most important to understand the interaction of at least one genetically dependent thrombophilia with one or more acquired conditions.

Determination of thrombophilic markers is necessary to evaluate the risk of thrombophilia in the examined patients. The degree of risk depends largely on the choice of methods for testing 
individual markers and their specificity. Another important reality in the interpretation of tests are interfering factors for each test.

Uncritical interpretation of laboratory results can lead to misdiagnosis and thrombophilia testing exemplifies this. If possible errors and overdiagnosis are to be avoided, the following points should be respected: Normal ranges for antithrombin and proteins C or S levels are wide and patients with deficiency may have levels that are only slightly below normal. Repeated testing is often required for diagnostic accuracy. For example, laboratory quality assurance data have shown that for protein $S$ in particular the rate of laboratory error in diagnosis can be as high as $20 \%$. Pregnancy induces a state of resistance to the anticoagulant effect of activated protein $C$, which mimics the presence of factor V Leiden. Pregnancy and OCP use lead to a fall in plasma protein $S$ concentration. Antithrombin concentration is reduced in acute thrombosis, by heparin treatment and in pre-eclampsia state. Proteins $C$ and $\mathrm{S}$ are vitamin $\mathrm{K}$ dependent and their concentrations are reduced by warfarin treatment. Even if the above potential pitfalls are avoided, there is no indication to routine testing for heritable thrombophilia at presentation with acute VTE, as clinical management is not influenced by the results.

Concerning the determination of mutation FII 20210 G / A, the situation is quite the opposite. Screening test shows high interference with the current status, therefore it is completely unusable and direct molecular genetic analysis of point mutations FII 20210 G-A.

The identification of potential genetic causes of thrombophilia, such as mutation of fibrinogen, platelet receptor, PAI-1, F VII and homocysteine are designed for testing the rare causes of thrombophilia in thrombotic centers. Howeever, they can be beneficial to clarify complex cases of thrombophilia especially if associated with repeated manifestations in the family.

Genetic testing is a separate part of the diagnosis of thrombophilia. Generally, it is not intended for screening the universal population, but only to determine the causes of thrombophilia in defined groups of patients - young patients with a positive family history of thrombophilia, in patients with previous thrombosis under 45 years of age, patients with the manifestation of thrombosis in an unusual site (e.g. portal vein), and at women in pregnancy or with using oral contraceptives.

\section{Author details}

\section{Ludek Slavik*}

Address all correspondence to: ludek.slavik@fnol.cz

Hemato-oncology Clinic, Faculty of Medicine and Dentistry Palacky University Olomouc, Czech Republic 


\section{References}

[1] Picard V, Prescot I, Scarabin PY, et al. Antithrombin Cambridge II (A384S): Prevalence in patients of the Paris Thrombosis Study (PATHROS). Blood 2007; 110: 2777-2778.

[2] Vorlova Z., Hrachovinova I., Matyskova M. Probability of thrombosis in patients with factor V Leiden. Thromb.Haemost. 1997; 78/1:309.

[3] Chrobák, L., Dulíček, P.: Resistance to activated protein C as pathogenic factor of venous thromboembolism. - Acta Medica (Hradec Králové). - 1996; 39,(2):55-62.

[4] Martinelli I, Mannucci PM, De Stefano V, et al. Different sisks of thrombosis in four coagulation defects associated with inherited thrombophilia: a study of 150 families. Blood 1998; 92: 2353-2358

[5] Hluší, A., Slavík, L., Úlehlová, J., Krčová, V., Indrák, K. Global assessment of haemostagic function - Part I. Thrombin generation test Transfuze a Hematologie Dnes 2010;16 (2), pp. 65-70

[6] Egeberg O. Inherited antithrombin deficiency causing thrombophilia. Thromb Diath Haemorrh. 1965; 13:516-530.

[7] Thaler E, Lechner K. Antithrombin III deficiency and thromboembolism. Clin Haematol. $1981 ; 10: 369-390$.

[8] Demers C, Ginsberg JS, Hirsh J, Henderson P, Blajchman MA. Thrombosis in antithrombin III deficient persons: report of a large kindred and literature review. Ann Intern Med. 1992; 116:754-761.

[9] Hirsh J, Piovella F, Pini M. Congenital antithrombin III deficiency: incidence and clinical features. Am J Med. 1989; 87:34-38.

[10] Lane DA, Mannucci PM, Bauer KA, Bertina RM, Bochkov NP, Boulyjenkov V et al. Inherited Thrombophilia: Part 1. Thromb Haemost. 1996; 76:651-662.

[11] Khor B,Van Cott EM. Laboratory tests for antithrombin deficiency. Am J Hematol 2010; 85: 947-950.

[12] Ungerstedt JS,Schulman S,Egberg N, et al. Discrepancy between antithrombin activity methods revealed in Antithrombin Stockholm: Do factor Xa-based methods overestimate antithrombin activity in some patients? Blood 2002; 99: 2271-2272.

[13] Lindahl TL,Baghaei F,Blixter IF, et al. Effects of the oral, direct thrombin inhibitor dabigatran on five common coagulation assays. Thromb Haemost 2011; 105: 371-378.

[14] Rossi E,Chiusolo P,Za T, et al. Report of a novel kindred with antithrombin heparinbinding site variant (47 Arg to His): Demand for an automated progressive antithrombin assay to detect molecular variants with low thrombotic risk. Thromb Haemost 2007; 98: 695-697.

[15] Tait RC,Walker ID,Perry DJ, et al. Prevalence of antithrombin deficiency in the healthy population. Br J Haematol 1994; 87: 106-112. 
[16] Corral J,Hernandez-Espinosa D,Soria JM, et al. Antithrombin Cambridge II (A384S): An underestimated genetic risk factor for venous thrombosis. Blood 2007; 109: 42584263.

[17] Griffin JH, Evatt B, Zimmerman TS, Kleiss AJ, Wideman C. Deficiency of protein C in congenital thrombotic disease. J Clin Invest. 1981; 68:1370-1373.

[18] Allaart CF, Poort SR, Rosendaal FR, Reitsma PH, Bertina RM, Briët E. Increased risk of venous thrombosis in carriers of protein C deficiency defect. Lancet. 1993; 341:134-138.

[19] Broekmans AW, Veltkamp JJ, Bertina RM. Congenital protein C deficiency and venous thromboembolism: a study of three Dutch families. N Engl J Med. 1983; 309:340-344.

[20] Allaart CF, Poort SR, Rosendaal FR, Reitsma PH, Bertina RM, Briët E. Increased risk of venous thrombosis in carriers of protein C deficiency defect. Lancet. 1993; 341:134-138.

[21] Koeleman BPC, Reitsma PH, Allaart CF, Bertina RM. APC-resistance as an additional risk factor for thrombosis in protein C deficient families. Blood. 1994; 84:1031-1035.

[22] Heijboer H, Brandjes DPM, Büller HR, Sturk A, Ten Cate JW. Deficiencies of coagulation-inhibiting and fibrinolytic proteins in outpatients with deep-vein thrombosis. $\mathrm{N}$ Engl J Med. 1990; 323:1512-1516.

[23] Mateo J, Oliver A, Borrell M, Sala N, Fontcuberta J, the EMET Group. Laboratory evaluation and clinical characteristics of 2,132 consecutive unselected patients with venous thromboembolism-results of the Spanish multicentric study on thrombophilia(EMET-study). Thromb Haemost. 1997; 77: 444-451.

[24] Cooper PC,Cooper SM,Goodfellow KJ, et al. Evaluation of a new venom-based clotting assay of protein C. Int J Lab Hematol 2008; 30: 437-443.

[25] Cooper PC,Siddiq S,Morse C, et al. Marked discrepancy between coagulometric protein $\mathrm{C}$ activity assays with the pro-thrombotic protein C Asn2Ile substitution. Int J Lab Hematol 2011; 33: 451-456.

[26] Walker I.D. et al. Guidelines on the Investigation and Management of Thrombophilia. J. Clin Path, 43, 1990, 703 - 709.

[27] Walenga JM,Drenth AF,Mayuga M, et al. Transition from argatroban to oral anticoagulation with phenprocoumon or acenocoumarol: Effect on coagulation factor testing. Clin Appl Thromb Hemost 2008; 14: 325-331.

[28] D'Angelo SV,Mazzola G,Della Valle P, et al. Variable interference of activated protein $\mathrm{C}$ resistance in the measurement of protein $\mathrm{S}$ activity by commercial assays. Thromb Res 1995; 77: 375.

[29] Faioni EM,Boyer-Neumann C,Franchi F, et al. Another protein S functional assay is sensitive to resistance to activated protein C. Thromb Haemost 1994; 72: 648.

[30] Jennings I,Kitchen S,Cooper P, et al. Sensitivity of functional protein $S$ assays to protein S deficiency: A comparative study of three commercial kits. J Thromb Haemost 2003; 1: 1112 .

[31] Khor B,Van Cott EM. Laboratory evaluation of hypercoagulability. Clin Lab Med 2009; 29: 339-366. 
[32] Marlar RA,Gausman JN. Protein S Abnormalities: A diagnostic nightmare. Am J Hematol 2011; 86: 418-421.

[33] Rodeghiero F, Tosetto A. Activated protein C resistance and factor V Leiden mutation are independent risk factors for venous thromboembolism. Ann Intern Med 1999; 130: 643-50.

[34] Gibson NJ (2007) The use of real-time PCR methods in DNA sequence variation analysis. Mol Cell Probes 363:171-176

[35] Sevall JS (2001) Rapid allelic discrimination from real-time DNA amplification. Methods 25:452-455

[36] Didenko VV (2001) DNA probes using fluorescence resonance energy transfer (FRET): designs and applications. Biotechniques 31(5):1106-1121

[37] Holland PM, Abramson RD, Watson R, Gelfand DH (2001) Detection of specific polymerase chain reaction product by utilizing the $5^{\prime}-3^{\prime}$ exonuclease activity of Thermus aquaticus DNA polymerase. Biochemistry 88:7276-7280

[38] Lay MJ, Wittwer CT (1997) Real-time fluorescence genotyping of factor V Leiden during rapid-cycle PCR. ClinChem 43(12):2262-2267

[39] Liew M, Pryor R, Palais R, Meadows C, Erali M, Lyon E, Wittwer C (2004) Genotyping of single-nucleotide polymorphisms by high-resolution melting of small amplicons. Clin Chem 50(7):1156-1164

[40] Parks SB, Popovich BW, Press RD (2001) Real-time polymerase chain reaction with fluorescent hybridization probes for the detection of prevalent mutations causing common thrombophilic and iron overload phenotypes. Am J Clin Pathol 115:439-447

[41] Wittwer CT, Reed GH, Gundry CN, Vandersteen JG, Pryor RJ. High-resolution genotyping by amplicon melting analysis using LCGreen. Clin Chem 2003;49:853-60.

[42] Lay MJ, Wittwer CT. Real-time fluorescence genotyping of factor V Leiden during rapid-cycle PCR. Clin Chem 1997;43:2262-2267.

[43] Livak KJ, Flood SJ, Marmaro J, Giusti W, Deetz K. Oligonucleotides with fluorescent dyes at opposite ends provide a quenched probe system useful for detecting PCR product and nucleic acid hybridization. PCR Methods Appl 1995;4:357-362.

[44] Crockett AO, Wittwer CT. Fluorescein-labeled oligonucleotides for real-time pcr: using the inherent quenching of deoxyguanosine nucleotides. Anal Biochem 2001;290:89-97.

[45] Angelini A, Di Febbo C, Baccante G, Di Nisio M, Di Ilio C, Cuccurullo F, Porreca E. Identification of three genetic risk factors for venous thrombosis using a multiplex allele-specific PCR assay: comparison of conventional and new alternative methods for the preparation of DNA from clinical samples. J Thromb Thrombolysis. 2003 Dec;16(3): 189-93.

[46] Ugozzoli LA, Hamby K. Four-color multiplex 5' nuclease assay for the simultaneous detection of the factor V Leiden and the prothrombin G20210A mutations. Mol Cell Probes. 2004 Jun;18(3):161-6. 
[47] Bianchi M, Emanuele E, Davin A, Gagliardi S, Cova E, Meli V, Trotti R, Cereda C. Comparison of three methods for genotyping of prothrombotic polymorphisms. Clin Exp Med. 2010 Dec;10(4):269-72. Epub 2010 Apr 29.

[48] Reitsma PH, Rosendaal FR. Past and future of genetic research in thrombosis. J Thromb Haemost. 2007, Jul 5; Suppl 1:264-9.

[49] Rees DC, Cox M, Clegg JB. World distribution of factor V Leiden. Lancet. 1995; 346:1133-1134.

[50] Rosendaal FR, Koster T, Vandenbroucke JP, Reitsma PH. High risk of thrombosis in patients homozygous for factor V Leiden (activated protein C resistance). Blood. 1995; 85:1504-1508.23.

[51] Ridker PM, Miletich JP, Hennekens CH, Buring JE. Ethnic distribution of factor V Leiden in 4047 men and women. JAMA. 1997; 277, 1305-1307.

[52] Vorlova Z., Hrachovinova I., Matyskova M. Probability of thrombosis in patients with factor V Leiden. Thromb.Haemost. 1997; 78/1:309.

[53] Chrobák, L., Dulíček, P.: Resistance to activated protein C as pathogenic factor of venous thromboembolism. - Acta Medica (Hradec Králové). - 1996; 39,(2):55-62.

[54] Dulíček P., Šafářová M., Chrobák L. Mutace FV Leiden - nejčastější rizikový faktor pro vznik žilní trombózy. Hematológia a transfuziológia. 1997; 4:6-9.

[55] Bertina RM, Koeleman RPC, Koster T, Rosendaal FR, Dirven RJ, De Ronde H et al. Mutation in blood coagulation factor $\mathrm{V}$ associated with resistance to activated protein C. Nature. 1994; 369:64-67.

[56] Dahlbäck B, Carlsson M, Svensson PJ. Familial thrombophilia due to a previously unrecognised mechanism characterized by poor anticoagulant response to activated protein C: prediction of a cofactor to activated protein C. Proc Natl Acad Sci USA. 1993; 90:1004-1008.

[57] Koster T, Rosendaal FR, De Ronde H, Briët E, Vandenbroucke JP, Bertina RM. Venous thrombosis due to a poor anticoagulant response to activated protein C: Leiden Thrombophilia Study. Lancet. 1993; 342:1503-1506.

[58] Ridker PM, Hennekens CH, Lindpainter K, Stampfer MJ, Eisenberg PR, Miletich JP. Mutation in the gene coding for coagulation factor $\mathrm{V}$ and the risk of myocardial infarction, stroke, and venous thrombosis in apparently healthy men. N Engl J Med. 1995; 332:912-917.

[59] Anderson FA, Wheeler HB, Goldberg RJ, Hosmer DW, Patwardhan NA, Jovanovic B et al. A population based perspective of the hospital incidence and case-fatality rates of deep vein thrombosis and pulmonary embolism. The Worcester DVT study. Arch Intern Med. 1991; 151:933-938.

[60] Cripe LD, Moore KD, Kane WH. Structure of the gene for human coagulation factor V. Biochemistry 1992; 31: 3777-3785.

[61] Jenny RJ, Pittman DD, Toole JJ, et al. Complete cDNA and derived amino acid sequence of human factor V. Proc Natl Acad Sci USA 1987; 84: 4846-4850. 
[62] Segers K., Dahlbäck B, Nicolaes G. Coagulation factor V and thrombophilia: Background and mechanisms. Thromb Haemost. 2007 Sep; 98(3):530-42.

[63] Husten EJ, Esmon CT, Johnson AE. The active site of blood coagulation factor Xa. Its distance from the phospholipid surface and its conformational sensitivity to components of the prothrombinase complex. J Biol Chem 1987; 262: 12953-12961.

[64] Yegneswaran S, Fernandez JA, Griffin JH. Factor Va increases the affinity of factor Xa for prothrombin: a binding study using a novel photoactivable thiol-specific fluorescent probe. Chem Biol 2002; 9: 485-494.

[65] Dahlbäck B, Carlsson M, Svensson PJ. Familial thrombophilia due to a previously unrecognized mechanism characterized by poor anticoagulant response to activated protein C: prediction of a cofactor to activated protein C. Proc Natl Acad Sci USA 1993; 90:1004-1008.

[66] Poort SR, Rosendaal FR, Reitsma PH, Bertina RM. A common genetic variation in the 3 '-untranslated region of the prothrombin gene is associated with elevated plasma prothrombin levels and an increase in venous thrombosis. Blood. 1996; 88:3698-3703.

[67] Poort, S. R.; Rosendaal, F. R.; Reitsma, P. H.; Bertina, R. M. : A common genetic variation in the 3-prime-untranslated region of the prothrombin gene is associated with elevated plasma prothrombin levels and an increase in venous thrombosis. Blood 88: 3698-3703, 1996.

[68] Gehring, N. H.; Frede, U.; Neu-Yilik, G.; Hundsdoerfer, P.; Vetter, B.; Hentze, M. W.; Kulozik, A. E. : Increased efficiency of mRNA 3-prime end formation: a new genetic mechanism contributing to hereditary thrombophilia. Nature Genet. 28: 389-392, 2001.

[69] Eleanor S. Pollak, Ho-Sun Lam, and J. Eric Russell The G20210A mutation does not affect the stability of prothrombin mRNA in vivo. Blood $2002 ; 100(1): 359-62$.

[70] Ceelie H, Spaargaren-van Riel CC, Bertina RM, Vos HL. G20210A is a functional mutation in the prothrombin gene; effect on protein levels and 3'-end formation. J Thromb Haemost. 2: 119-27. 2004

[71] Rosendaal, F. R.; Doggen, C. J. M.; Zivelin, A.; Arruda, V. R.; Aiach, M.; Siscovick, D. S.; Hillarp, A.; Watzke, H. H.; Bernardi, F.; Cumming, A. M.; Preston, F. E.; Reitsma, P. H. : Geographic distribution of the $20210 \mathrm{G}$ to a prothrombin variant. Thromb. Haemost. 79: 706-708, 1998.

[72] Rosendaal FR, Doggen CJM, Zivelin A, Arruda VR, Aiach M, Siscovick DS et al. Geographic distribution of the $20210 \mathrm{G}$ to A prothrombin variant. Thromb Haemost. 1998; 79:706-708.

[73] Zivelin, A.; Rosenberg, N.; Faier, S.; Kornbrot, N.; Peretz, H.; Mannhalter, C.; Horellou, M. H.; Seligsohn, U. : A single genetic origin for the common prothrombotic G20210A polymorphism in the prothrombin gene. Blood 92: 1119-1124, 1998.

[74] Rees, D. C.; Chapman, N. H.; Webster, M. T.; Guerreiro, J. F.; Rochette, J.; Clegg, J. B. : Born to clot: the European burden. Brit. J. Haemat. 105: 564-566, 1999.

[75] Matýšková M., Buliková A., Šlechtová M., Janků L. The prevalence of the prothrombin mutation 20210A in Brno, XV meeting of the ISH - African and European division, Final programme and abstracts, 124. 
[76] Souto JC, Coll I, Llobet D, del Río E, Oliver A, Mateo J, Borrell M et al. The prothrombin 20210A allele is the most present genetic risk factor for venous thromboembolism in the Spanish population. Thromb Haemost. 1998; 80:366-369.

[77] Pihusch, R.; Buchholz, T.; Lohse, P.; Rubsamen, H.; Rogenhofer, N.; Hasbargen, U.; Hiller, E.; Thaler, C. J. : Thrombophilic gene mutations and recurrent spontaneous abortion: prothrombin mutation increases the risk in the first trimester. Am. J. Reprod. Immun. 2001, 46: 124-131.

[78] Samama MM, Rached RA, Horellou MH, Aquilanti S, Mathieux VG, Bureau G, Elalamy I, Conard J. Pregnancy-associated venous thromboembolism (VTE) in combined heterozygous factor V Leiden (FVL) and prothrombin (FII) 20210 A mutation and in heterozygous FII single gene mutation alone. British Journal of Haematology, 123, 327334, 2003.

[79] Casas, J. P.; Hingorani, A. D.; Bautista, L. E.; Sharma, P. : Meta-analysis of genetic studies in ischemic stroke: thirty-two genes involving approximately 18000 cases and 58000 controls. Arch. Neurol. 61: 1652-1662, 2004.

[80] De Stefano, V.; Martinelli, I.; Mannucci, P. M.; Paciaroni, K.; Chiusolo, P.; Casorelli, I.;Rossi, E.; Leone, G. : The risk of recurrent deep venous thrombosis among heterozygous carriers of both factor V Leiden and the G20210A prothrombin mutation. New Eng. J. Med. 341: 801-806, 1999.

[81] Grubic N, Stegnar M, Peternel P, Kaider A, and Binder BR. A novel G/A and the $4 \mathrm{G} / 5 \mathrm{G}$ polymorphism within the promoter of the plasminogen activator inhibitor-1 gene in patients with deep vein thrombosis. Thromb Res 84: 431 443, 1996.

[82] Binder BR, Christ G, Gruber F, Grubic N, Hufnagl P, Krebs M, Mihaly J, Prager GW. Plasminogen activator inhibitor 1: physiological and pathophysiological roles. News Physiol Sci. 2002 Apr;17:56-61.

[83] Meade TW, Mellows S, Brozovic M, Miller GJ, Chakrabarti RR, North WR, et al. Haemostatic function and ischaemic heart disease: principal results of the Northwick Park Heart Study. Lancet 1986;2:533-537.

[84] Heinrich J, Balleisen L, Schulte H, Assmann G, van de Loo J. Fibrinogen and factor VII in the prediction of coronary risk: results from the PROCAM study in healthy men. Arterioscler Thromb 1994;14:54-59.

[85] Folsom AR. Haemostatic risk factors for atherothrombotic disease: an epidemiologic view. Thromb Haemost 2001;86:366-373.

[86] Behague I, Poirier O, Nicaud V, Evans A, Arveiler D, Luc G, et al. Beta fibrinogen gene polymorphisms are associated with plasma fibrinogen and coronary artery disease in patients with myocardial infarction: The ECTIM Study. Etude Cas-temoins sur I'Infarctus du Myocarde. Circulation 1996;93:440-449.

[87] Carvalho de Sousa J, Bruckert E, Giral P, Soria C, Truffert J, Mirshami MC, de Gennes JL, Caen JP Plasma factor VII, triglyceride concentration and fibrin degradation products in primary hyperlipidemia:a clinical and laboratory study. Haemostasis, 1989; 19(2):83-90. 
[88] Green F, Kelleher C, Wilkes H, Temple A, Meade T, Humphries S. A common genetic polymorphism associated with lower coagulation factor VII levels in healthy individuals. Arterioscler Thromb 1991;11:540-546.

[89] Iacoviello L, Di Castelnuovo A, De Knijff P, D'Orazio A, Amore C, Arboretti R, et al. Polymorphism in the coagulation factor VII gene and the risk of myocardial infarction. N Engl J Med 1998;338:79-85.

[90] Corral J, González-Conejero R, Lozano ML, Rivera J, Vicente V. Genetic polymorphisms of factor VII are not associated with arterial thrombosis. Blood Coagul Fibrinolysis 1998;9:267-272.

[91] Ekström M, Silveira A, Bennermo M, Eriksson P, Tornvall P. Coagulation factor VII and inflammatory markers in patients with coronary heart disease. Blood Coagul Fibrinolysis 2007;18:473-477.

[92] Newman PJ, Derbes RS, Aster RH. The human platelet alloantigens, PIA1 and PIA2, are associated with a leucine 33/proline33 amino acid polymorphism in membrane glycoprotein IIIa, and are distinguishable by DNA typing. J Clin Invest 1989;83:1778-1781.

[93] Weiss EJ, Bray PF, Tayback M, Schulman SP, Kickler TS, Becker Isordia-Salas et al. Volume 78, No. 1, January-February 201091

[94] Carter AM, Catto AJ, Bamford JM, Grant PJ. Platelet GP IIIa PIA and GP Ib variable number tandem repeat polymorphism and markers of platelet activation in acute stroke. Arterioscler Thromb Vasc Biol 1998;18:1124-1131.

[95] Mikkelsson J, Perola M, Laippala P, Savolainen V, Pajarinen J, Lalu K, et al. Glycoprotein IIIa PI (A) polymorphism associates with progression of coronary artery disease and with myocardial infarction in an autopsy series of middle-aged men who died suddenly. Arterioscler Thromb Vasc Biol 1999;19:2573-2578.

[96] Falcon CR, Cattaneo M, Panzeri D, Martinelli I, Mannucci PM. High prevalence of hyperhomocyst(e)inemia in patients with juvenile venous thrombosis. Arterioscler Thromb. 1994; 14:1080-1083.

[97] Den Heijer M, Koster T, Blom HJ, Bos GMJ, Briët E, Reitsma PH et al. Hyperhomocysteinemia as a risk factor for deep-vein thrombosis. N Engl J Med. 1996; 334:759-762.

[98] Simioni P, Prandoni P, Burlina A, Tormene D, Sardella C, Ferrari V et al. Hyperhomocysteinemia and deep-vein thrombosis: a case-control study. Thromb Haemost. 1996; 76:883-886.

[99] Hyánek J., Hoffman R. Hyperhomocysteinémie a její diagnostický význam u cévních onemocnění. Praktická flebologie. 1997; 2:61-71.

[100] D'Angelo A, Selhub J. Homocysteine and thrombotic disease. Blood. 1997; 90:1-11.

[101] Kang SS, Wong PWK, Norusis M. Homocysteinemia due to folate deficiency. Metabolism. 1987; 36:458-462.

[102] Kang SS, Zhou J, Wong PW, Kowalisyn J, Strokosch G. Intermediate homocysteinemia: a thermolabile variant of methylenetetrahydrofolate reductase. Am J Hum Genet. 1988; 43(4):414-21. 
[103] Rees MM, Rodgers GM. Homocysteinemia: association of a metabolic disorder with vascular disease and thrombosis. Thrombosis Research. 1993; 71:337-359.

[104] Ubbink JB, Vermaak WJ, Van der Merwe A, Becker PJ. Vitamin B12, vitamin B6, and folate nutritional status in men with hyperhomocysteinemia. Am J Clin Nutr. 1993; 57:47-53.

[105] Mudd SH, Skovby F, Levy HL, Pettigrew KD, Wilcken B, Pyeritz RE et al. The natural history of homocystinuria due to cystathionine beta-synthase deficiency. Am J Hum Genet. 1985; 37:1-31.

[106] Engbertsen AMT, Franken DG, Boers GHJ, Stevens EMB, Grijbels FJM, Blom HJ. Thermolabile 5,10-methylenetetrahydrofolate reductase as a cause of mild hyperhomocysteinemia. Am J Hum Genet. 1995; 56:142-150.

[107] Frosst P, Blom HJ, Milos R, Goyette P, Sheppard CA, Matthews RG et al. A candidate genetic risk factor for vascular disease: a common mutation in methylenetetrahydrofolate reductase. Nat Genet. 1995; 10:111-113. 
